\title{
Seasonal Changes in Organic Acid Levels in Satsuma Mandarin Fruit*
}

\author{
Akiyoshi Matsumoto and Shin-ichi Shiraishi \\ Fukuoka Horticultural Experiment Station, \\ Kashiwara, Minami-ku, Fukuoka 815
}

\begin{abstract}
Summary
The first rapid increase of organic acid concentration in very young satsuma mandarin fruit (C. unshiu Marc.) may be related to transformation of sugars into malic acid via the addition of $\mathrm{CO}_{2}$ to pyruvate. The decrease in organic acid concentration after the maximum is caused by both the dilution from fruit enlargement and an actual reduction in the absolute amount of citric acid. Differences in the characteristics of maturity among strains of satsuma mandarin are associated more with changes in the absolute amounts of citric acid in the pulp than with its concentrations. The late-maturing Fukuhara attained a maximum in its absolute amount of citric acid later in the season than the early-maturing satsuma strains.
\end{abstract}

\section{Introduction}

Sugars and organic acids are thought to be the most important factors for determining the taste of citrus fruits.

In present marketing channels, the con centration of organic acids is important. Seasonal changes in the concentration of organic acids in citrus fruits have been frequently investigated in Japan $(3,4,5)$. However, in most of these studies, fruit size varied and sampling intervals were too long.

Many data were limited to the stage very close to the harvest time. Many of the above limitations were associated with the quantitative limitation of silicic gel column chromatography which has been used in the analyses of organic acids.

This limitation can be overcome using gas liquid chromatography (GLC), by converting organic acids to 1-butyl esters and analyzing the ester mixtures, a procedure recently applied to fruit analysis by Yamashita et al. (11). In the present study, seasonal changes in the organic acid content of several satsuma mandarin strains were precisely analyzed using GLC from the beginning of the fruit

Received for publication July 3, 1980.

* Studies on the Organic Acids of Citrus Fruits (VII). growth through the senescent period.

It was found that the degree of fluctuation in the levels of organic acids depend upon the strains, and that the absolute amount, rather than the concentration of citric acid was associated with the differences in the characteristics of maturity among the strains.

\section{Materials and Methods}

Three strains of satsuma mandarin, Miya gawa wase unshiu (Miyagawa), Sugiyama futsu unshiu (Sugiyama) and Imamura futsu unshiu (Imamura) were planted at the Fukuoka Horticultural Experiment Station. Two trees of each strain were used for study. Fukuhara orange (C. sinensis Osbeck) was also used as a control variety. Fruit sampling periods began in July, 1974 and finished in November, 1974 for the Sugiyama, in February, 1975 for the Miyagawa and Imamura, and in April, 1975 for the Fukuhara. Thirty fruits, randomly selected from around the trees, were labeled and the diameter of these fruits were measured every week through December, and every two weeks thereafter. Fruits with the same diameter were obtained for data on fresh weight of whole fruit and pulp (peeled fruit) and titratable acidity in the pulp. On the basis of the seasonal fluctuation of the concentrations and the absolute amounts of titra- 
Table 1. Changes in fruit weight during development.

\begin{tabular}{r|c|c|c|c}
\hline & \multicolumn{4}{|c|}{ Variety and strain $(\mathrm{g})$} \\
\cline { 2 - 5 } Date & \multicolumn{3}{|c|}{ Satsuma } & Sweet orange \\
\cline { 2 - 5 } & Miyagawa & Sugiyama & Imamura & Fukuhara \\
\hline '74 J 22 & 13.9 & 10.8 & 10.9 & 19.8 \\
29 & 19.3 & 15.1 & 14.9 & 25.7 \\
A 5 & 21.3 & 22.2 & 18.5 & 34.7 \\
12 & 25.6 & 26.7 & 20.3 & 39.1 \\
S 2 & 50.6 & 52.2 & 49.2 & 70.4 \\
9 & 55.5 & 56.1 & 52.6 & 76.6 \\
O 5 & 76.1 & 90.8 & 70.9 & 103.4 \\
14 & 86.7 & 96.7 & 83.2 & 109.0 \\
N11 & 97.9 & 106.0 & 100.0 & 135.4 \\
18 & 95.1 & 106.3 & 101.2 & 141.6 \\
D 9 & 92.6 & - & 99.0 & - \\
'75 J 20 & 86.5 & - & 97.7 & 148.5 \\
F 3 & 87.5 & - & 100.0 & 145.0 \\
17 & 87.8 & - & 98.0 & 145.5 \\
M17 & - & - & - & 143.3 \\
A 4 & - & - & - & 146.0 \\
\hline
\end{tabular}

table acidity, several periods were selected for GLC analyses of organic acids in the pulp according to Yamashita et al. (4).

\section{Results and Discussion}

Data on flesh fruit weight (Table 1) suggest that fruit growth for each strain and variety was normal.

Formic, acetic, oxalic, malonic, succinic, malic and citric acids were found as sharp symmetric peaks in the chromatograms. Citric acid was dominant, followed by malic acid; other acids were minor, and their data will be omitted from this report.

Concentration of organic acids in the pulp.

The concentration of citric acid was low when fruit was very young but increased rapidly as it grew. In Miyagawa and Sugiyama, the concentrations reached the maxima in early August, and in Imamura, in early September. Then concentrations decreased gradually as the fruit matured (Fig. 1). The citric acid concentrations in both mandarins (6) and oranges $(1,7,8,10)$ have maxima during summer and autumn, but no clear relationship was found between the citric acid concentration and the maturation characteristics $(1,7,8,10)$.

In the present study, it was clearly demon-

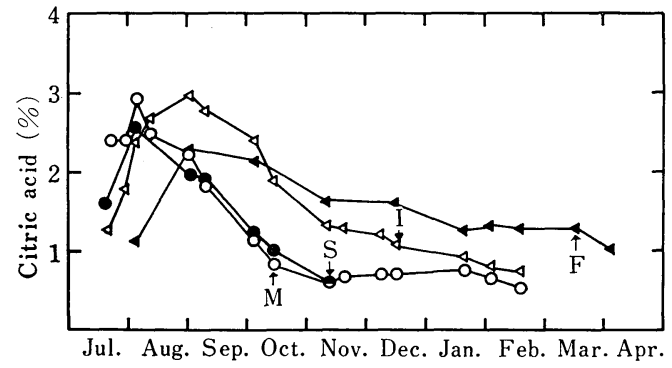

Fig.1. Changes in the citric acid concentration in the pulp during fruit development. (O) : Miyagawa, (O) : Sugiyama, $(\triangle)$ : Imamura, $(\boldsymbol{\Delta})$ : Fukuhara, $(\mathrm{M}, \mathrm{S}, \mathrm{I}, \mathrm{F})$ : Harvest times of Miyagawa, Sugiyama, Imamura, and Fukuhara, respectively.

strated that early-maturing Miyagawa and latematuring Sugiyama had peaks at almost the same time, and the other latematuring Imamura had the peak about a month later. Though Miyagawa and Imamura had different citric acid concentrations at their harvest times, the concentrations at their maxima were similar. The same lack of relation was found when a comparison was made between the varieties, satsuma mandarin and orange. Thus we concluded that there is no clear interrelationship between the maturation characteristics and the citric acid concentration.

In general, the differences among variet:es and strains were smaller for malic acid than for citric acid concentrations. The pattern of seasonal changes in the concentration of malic acid was divided in to two types according to the strains (Fig. 2). Imamura had a peak at about mid-August on the malic acid concentration curve. The other strains and Fukuhara failed to show peaks, but younger fruit showed higher concentrations. Somewhat similar results have been obtained for

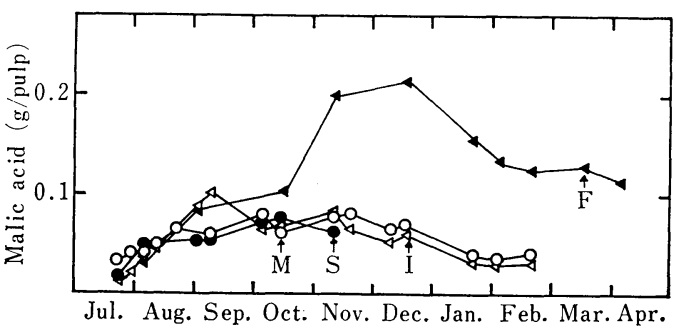

Fig. 2. Changes in the malic acid concentration in the pulp during fruit development. Symbols are the same as in Fig.1 


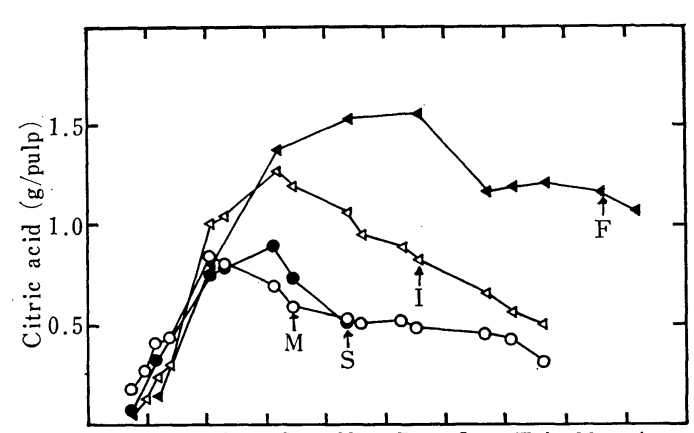

Jul. Aug. Sep. Oct. Nov. Dec. Jan. Feb. Mar. Apr.

Fig.3. Seasonal changes in the absolute amount of citric acid in the fruit pulp. (O) : Miyagawa,

(O): Sugiyama, $(\triangle)$ : Imamura, ( $\mathbf{\Delta})$ : Fukuhara, (M, S, I, F) : Harvest times of Miyagawa, Sugiyama, Imamura, and Fukuhara, respectively.

malic acid concentrations in other citrus fruits $(1,6,7,9,10)$.

A higher malic acid concentration in young fruit may be explained by the hypothesis that, during this period, sugars transported from leaves are changed into acids through glycolysis, and that the addition of $\mathrm{CO}_{2}$ to pyruvate is preferred over the conversion of pyruvate to citric acid via acetyl-Co A (2).

Content of organic acids in the pulp. The absolute amount of citric acid per fruit was very low in young fruit, but increased rapidly during fruit growth. Miyagawa reached its maximum value in early September; Imamura and Sugiyama, in early October. The amounts then decreased until harvest time (Fig. 3). Fukuhara followed almost the same tendency; the value reached its maximum in early November, remained unchanged about two months, then decreased. Similar results have been obtained by Kakiuchi et al. $(3,4)$ who found the maxima in early September with early-maturing satsuma mandarin (wase unshiu), in early October with late-maturing satsuma mandaring (futsu unshiu) and in the middle of November for Fukuhara orange.

Sinclair and Ramsey (9) reported that the decrease of citric acid concentration in the late period of fruit growth was explained simply by dilution due to fruit enlargement. However, data herein show that the absolute amount of citric acid decrease. Thus, the decrease in citric acid concentration in sa-

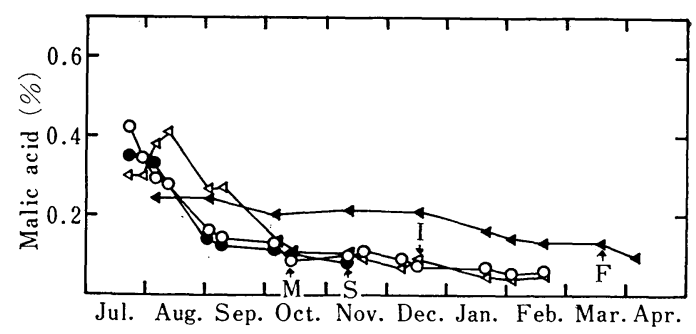

Fig.4. Seasonal changes in the absolute amount of malic acid in the fruit pulp. Symbols are the same as in Fig. 3.

tsuma mandarin may be caused by both dilution and higher degradation rates. It may be inferred that the gradual decrease in acid concentration after harvest time, or during senescense, is mainly brought about by the loss of citric and malic acid.

In the strains compared in the present study, Miyagawa (early-maturing) reached the maximum earliest, follwed by Sugiyama and Imamura (late-maturing) about a month later. Though Sugiyama showed lower levels of citric acid than Imamura throughout their life spans, their maxima were at the same time.

Consequently, it is suggested that the earlier the citric acid amount peaks, the earlier maturation occurs.

Satusma mandarin had a lower total amount of citric acid in the pulp at the harvest time and attained the maximum amount of citric acid earlier than the Fukuhara orange. For citric acid the absolute amount appears more highly associated with maturation characteristics between the two varieties compared than does citric acid concentration.

The malic acid content in a pulp increased as a fruit matured but decreased after harvest time (Fig. 4). This pattern was observed in all the strains studied. Fukuhara also exhibited this pattern. The malic acid content of Imamura in September may be exceptional. In oranges, malic acid content increases until autumn or winter, and gradually decreases thereafter $(4,7,9)$. Based on the relatively steady values of malic acid concentration through the fruit life of oranges, Rasmussen stated that malic acid was produced at about the rate it was diluted 
and metabolized (7). Our experiments confirm that this is also true for satsuma mandarin.

\section{Acknowledgement}

Authors wish to express their appreciation to Dr. Tom W. Embleton, Professor of California University, and to Dr. Katsumi Koga, Associate Professor of Kyushu University, for their valuable suggestions and for reading the manuscript.

\section{Literature Cited}

1. Clements, R. L. 1964. Organic acids in cit rus fruits. II. Seasonal changes in the orange. J. Food Sci. $29: 281-286$.

2. HUFFAKAKER, R.C. and A. WALlaCe. 1959. Dark fixation of $\mathrm{CO}_{2}$ in homogenates from citrus leaves, fruit and roots. Proc. Amer. Soc. Hort. Sci. $74: 348-357$.

3. KAKIUCHI, N., Y. IBA, and S. ITo. 1970. Fundamental studies of citrus juices. I. Seasonal changes of organic acids and sugars of satsuma mandarin. Bull. Hort. Res. Sta. B $10: 149-160$.

4. KAKIUCHI, N. and S. ITo. 1971. Fundamental studies of citrus juices. II. Seasonal changes of organic acids and sugars of Natsudaidai and Fukuhara orange. Bull. Hort. Res. Sta. B $11: 107-117$.

5. КUвота, S., H. FukUi, and S. AKaо. 1971.
Changes in concentrations of sugars, organic acids and amino acids in satsuma mandarin juice during growth of fruits. Bull. Shikoku Agr. Exp. Sta. $24: 73-96$.

6. Matsumoto, A. and S. Shiraishi. 1977. Studies on the organic acids of citrus fruits. II. Seasonal changes in the organic acids of various citrus fruits. Bull. Fukuoka Hort. Exp. Sta. $15: 18-28$.

7. RASMUSSEN, G. K. 1964. Seasonal changes in the organic acid content of Valencia orange fruit in Florida. Proc. Amer. Soc. Hort. Sci. 84 : 181-187.

8. Rasmussen, G. K., A. Paynado, R. Hilgeman, J. R. FURR, and G. CAHOON. 1966. The organic acid content of Valencia orange from four locations in the United States. Proc. Amer. Soc. Hort. Sci. 89 : 206-209.

9. Sinclair, W. B. and R. C. RAMSEY. 1944. Changes in the organic acid content of Valencia orange during development. Bot. Gaz. $106: 140-148$.

10. TING, S. V. and H. M. VINES. 1966. Organic acids in the juice vesicles of Florida Hamlin orange and Marsh seedless grapefruit. Proc. Amer. Soc. Hort. Sci. 88 : 291-297.

11. Yamashita, I., T. TAMURA, S. YoshiKaWA, T. Shimamoto, and A. Matsumoto. 1974. Determination of volatile and nonvolatile organic acids in fruits by gaschromatography. Bull. Agr. Chem. Soc. Jpn. 48(2) : 151-154.

\title{
ウンシュウミカン果実中の有機酸の時期的変化
}

\author{
松本明芳・白石真一 \\ (福岡県立園芸試験場)
}

\begin{abstract}
摘要
ウンシュウミカンの系統による有機酸の濃度及び絶対 量の時期的変化の違いを検討した. 対照品種として福原 オレンジを加えた.

ウンシュウミカンの幼果では有機酸濃度の著しい增加 が認められる.これは, この時期の果肉中リンゴ酸濃度 が他の時期に比較して高いことから考えて, 炭酸固定反 応が活発に進行したためと思われる. 果肉中の有機酸濃 度は, 最高値に達した後, 減少を示すが, これは果肉容

紿対量の減少の二つの効果が重なって生じることが明ら かとなった. ウンシュウミカンの系統による熟期の特性 は, クエン酸の濃度よりも, 絶対量によく表れた。 ま た, ウンシュウミカンより熟期の遅い福原オレンジはク エン酸の絶対量が最高值を示す時期がウンシュウミカン より遅かった。すなわち, 熟期の早い系統や品種ほど, 早い時期にクエン酸の消費が集積を上をわるようになっ た.
\end{abstract} 積の增大による希釈と, 有機酸, 中でる特にクエン酸の 